Aqui, urge a necessidade de um pré-requisito necessário a uma atividade comunicacional que vise a uma resposta consensual: fazer com que a parte mais interessada - a grande massa pauperizada e aquela que está em via de pauperização - force para a via do diálogo aqueles que detém os meios políticos e econômicos capazes de apresentar uma solụção para o problema.

Tal pré-requisito é o resgate da cidadania, traduzido pela ocupação de todos os espaços necessários ao exercício da reflexão e da ação que garantam os direitos dos cidadãos. Urge a reativação dos micropoderes da estrutura social - as associações de bairros, os movimentos populares por saúde e habitação, os sindicatos, as associações de pais e mestres, os centros cívicos e acadêmicos - a fim de que busquem melhores condições de trabalho e educação, motivados pela mesma atividade intercomunicacional. Esses micropoderes devem ser revitalizados por um único sentimento: o de ser ético acima de tudo, pois nele está implícita a possibilidade que resta aos integrantes desta massa miserável e anônima de avistarem o sentido mais pleno do ser.

Hamlet hesitou, diante do mal que o cercava, entre o ser o não ser. Quando se fez presente a possibilidade de vingar a morte de seu pai e salvar o seu reino da mão do usurpador, ele a retardou esperando pot uma oportunidade melhor, quem sabe ideal. $\measuredangle$ no momento em que seu impeto filial pôs frni ao seu ininigo mortal, já não the restava mais nada, acabando por sucumbir aos eteitos de um veneno letal

Que o resgate da cidadania não tarde ao ponto de merecer também um fim trágico, mas que seja exercido constantemente como expressão daqueles que optaram antes de tudo e diante de tudo por ser, no sentido mais amplo e fenomenológico do termo.

Pe. Edélcio Serafim Ottaviani é Doutor em Filosofia e vice-diretor da Pontifícia Faculdade de Teologia Nossa Senhora da Assunção.

\section{A HOMULIA EM SUA DIMENSÃO SIMBÓLICO-SACRAMUNTAL: NA BUSCA AINDA DE ACERTAR 40 ANOS DEPOIS DA SACROSANCTUM CONCILIUM}

\author{
Pe. Dr. Valeriano dos Santos Costa
}

Uma das recuperações da reforma litúrgica do Concílio Vaticano II é a homilia, cuja presença já era atestada na liturgia eucarística do século II. Justino de Roma, de quem recebemos a primeira indicação de um formulário completo de celebração eucarística, diz que "no dia que se chama do sol, celebra-se uma reunião de todos os que moram nas cidades ou nos campos, e aí se lêem, enquanto o tempo o permite, as Memórias dos apóstolos e os escritos dos profetas. Quando o leitor termina, o presidente faz uma exortação e um convite para imitarmos esses belos exemplos"1.

Portanto, a homilia era importante nos primeiros séculos. Tinha uma identidade muito definida. Não era um discurso moralista ou temático, mas um comentário querigmático-exortativo, a partir dos textos da liturgia. Era, então, uma peça litúrgica de considerável valor. Como tal, a homilia desaparece mais tarde, sendo substituída pela pregação, não necessariamente litúrgica, desvinculando-se, portanto, das normas fundamentais que regem a celebração litiricica.

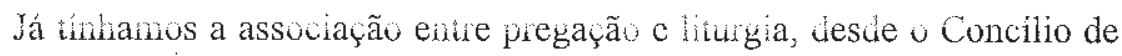
Trento, que noś trouxe, na sessão V, com o decreto Super Lectione et praedicatione, no dia 17 de junho de 1546, a primeira determinação de que a pregação fọsse obrigatória em todos os domingos e nos dias de preceito ${ }^{2}$.

Porém, como a pregação adquiriu um caráter não necessariamente litúrgico, a Constituição Sacrosanctum Concilitum (SC) retoma a "homilia"

'I Apologia, 67. In: JUSTINO DE ROMA. I e II Apologias. Diálogo com Trifão. São Paulo: Paulus, 1995. p. 83.

${ }^{2}$ Cf. JEDIN, H. Il concilio di Trento. v. II. Brescia: Morecelliana, 1962. p. 145-146. 
como o tipo de pregação a ser feita na liturgia e lhe dedica algumas linhas, ao tratar da Eucaristia:

Recomenda-se vivamente a homilia, como parte da própria liturgia; nela, no decurso do ano litúrgico, são apresentados, do texto sagrado; os mistérios da fé e as normas da vida cristã. Nas missas dominicais, porém, e nas festas

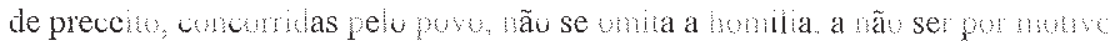
grave ${ }^{3}$.

Podemos extrair deste texto conciliar algumas afirmações sobre a homilia:

1. Faz parte do "próprio" da liturgia;

2. É recomendada em todas as celebrações eucarísticas;

3. Não pode ser omitida nos domingos e festas de preceito;

4. Tem como referência fundamental os textos sagrados ${ }^{4}$;

5. Faz a leitura dos mistérios da fé no contexto do ano litúrgico;

6. Apresenta sempre normas éticas atualizadas para a vida cristã.

A homilia é, portanto, o comentário, em contexto ritual, da Palavra proclamada e de outros textos litúrgicos. Não se trata de uma ação catequética, mas mistagógica, para ajudar a assembléia a aprofundar a experiência do mistério celebrado ativa, consciente e frutuosamente, não descuidando de dar indicações éticas para a vivência cristã, pois "(...) a liturgịa foi compreendida pelos Padres não unicamente como culto, mas qual norma de vida"s

\section{A HOMILIA NO CONTEXTO DA PREGAÇ̃̃o}

Os discípulos de Jesus são anunciadores da Palavra: Ide por todo o mundo e proclamai o Evangelho a toda criatura (Mc 16,15). A Palavra da

${ }^{3} \mathrm{SC} 52$.

${ }^{4}$ Aqui podemos entender os textos bíblicos e as orações próprias da Eucarística, os ditos textos eucológicos.

sPELLEGINO M. Liturgia e Padres. In: DI BERARDINO, Ângelo (Org.). Dicionário Patrístico e de antigüidades cristãs. Petrópolis: São Paulo: Vozes: Paulus, 2002. p. 834.
Boa-Notícia é o próprio Jesus encarnado, morto e ressuscitado para a glória de Deus e para a salvação da humanidade. A evangelização anuncia a sua presença e a celebração ritual o faz ser nossa experiência. A homilia, portanto, não apenas o anuncia, mas ajuda a assembléia orante a saborear a sua doce presença no mistério da liturgia.

Como pode, porém, a homilia manter suas caracieristicas liturgicas, se ela em si não é um rito, mas uma fala? Della Torre a define como a comunicação "não ritualizada" da palavra divina num contexto celebrativo ${ }^{6}$. De fato, a homilia não é em si um rito, pois não se repete, mas também não pode ser tratada fora do contexto celebrativo. Não se trata, portanto, de uma pregação catequética, realizada no púlpito ${ }^{7}$, o que pode ser feito fora da liturgia, mas, falando da Eucaristia ${ }^{8}$, de uma fala no interior da celebração litúrgica, encerrando o rito da Palavra e fazendo "ponte" com o rito sacramental. Neste sentido, a homilia tem a função de servir de conjunção entre Palavra e Sacramento e deve, como parte da liturgia da Palavra, aquecer o coração da assembléia para o rito sacramental, como ocorreu com os discípulos de Emaús (Lc 24,32) ${ }^{9}$, apontando também algumas indicações éticas em vista do testemunho e o compromisso dos cristãos.

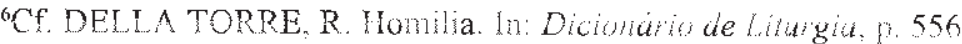

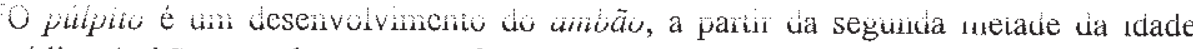
média. Ambão vem do grego anabainein $=$ subir. Faz parte da liturgia, desde que se começou a celebrar em igrejas construídas para tal fim. Chamou-se assim, porque sendo uma estante junto às cancelas para as leituras e a pregação, tinha sempre ưma ou duas escadas de acesso. Já o púlpito deslocou-se para o corpo da igreja, em lugar mais acessível para a comunicação que causasse impacto à assembléia. Neste sentido, o púlpito não se constituiu necessariamente uma peça litúrgica, ao passo que o ambão é essencialmente litúrgico. Cf. ROWER, Basílio. Dicionário de Liturgia. Petrópolis: Vozes, 1947. p. 23.

${ }^{8}$ Aqui falamos mais de homilia no interior de uma celebração sacramental, mas não podemoș nos esquecer que ela pode existir em qualquer celebração da Palavra, como é o caso das celebrações dominicais da Palavra na ausência de presbítero.

${ }^{9} \mathrm{Não}$ ardia o nosso coração quando ele nos falava pelo caminho, quando nos explicava as escrituras? 
Encontramos excelente indicação homilética no texto de Emaús, onde Jesus interpretou-lhes em todas as Escrituras o que a ele dizia respeito (Lc 24,27). Censurou-lhes também a incredulidade de coração e a dificuldade de aceitarem a cruz como método de vida e caminho de ressurreição (Lc 24,26). Com certeza, a maior resistência dos discípulos foi a aceitação da cruz ${ }^{10}$. Tinham medo até de perguntar sobre isto. porque certamente temiam a resposta (Lc 9,45). Ao contrário, sua ambição era a posição que ocupariam no reino político que, equivocadamente, pensavam que Jesus estava por instalar em Jerusalém (Lc 9,46-48; 22,24). Por isso, receberam ajuda do Ressuscitado para uma correta interpretação das Escrituras, em vista de uma postura adequada diante da vida e da missão que tinham pela frente. Examinando o texto de Emaús, podemos concluir a respeito do que estamọs tratando:

1. A homilia supõe uma pertinente exegese e hermenêutica das Escrituras, ou seja, é preciso ler o texto no contexto e saber aplicá-lo hoje;

2. Esta leitura é feita de forma cristã, isto é, interpretando nas Escrituras o que se diz de Jesus Cristo na perspectiva do seu Mistério Pascal;

3. Porém, isso tem que ser feito de forma litúrgica, já que quem faz esta interpretação e sua aplicação é o próprio Cristo. Isto é uma característica essencialmente litúrgica.

Embora a comunicação homilética não seja rigorosamente ritualizada, não podemos desconhecer, no entanto, seu caráter litúrgico e de entroncamento de dois ritos. Devido à sua tradição, é. purtanto. unia peça litúgica de naior grandeza. Porém, se não realizada como entroncamento e conjunção entre Palavra e Sacramento, pode representar uma quebra na ritualidade e perda para o conjunto da celebração. Por isso, a homilia tem-se constituído como um problema considerável. Se bem feita, é um trunfo, se mal feita, é um desastre. Há que se encarar a dificuldade, quarenta anos depois da Sacrosanctum

10 "As multidões esperavam um caudilho poderoso, cercado de atributos divinos. Esperavam dele sinais eficazes, uma intervenção poderosa da parte de Deus e de seu Messias na história do povo": RIUS-CAMPS, J. O Evangelho de Lucas: o êxodo do homem livre. São Paulo: Paulus, 1995. p. 228
Concilium, tentando compreender porque, muitas vezes, nossas liturgias chegam ao impasse de não conseguir levar a assembléia orante ao louvor de Deus e à santificação. Por que muitas pessoas saem da celebração eucarística descontes ou irritadas com as homilias? Antes de falarmos sobre a questão pastoral, vejamos alguns fundamentos teológico-bíblicos.

\section{FUNDAMENTOS BÍBLICOS E PATRISTICOS DA HOMUIA}

No Antigo Testamento, era em torno da Palavra que o povo se reunia para celebrar a Aliança e renovar os votos de fidelidade. Justamente essa renovação dos votos durante a convocação sagrada passava por um momento de interpretação e partilha da palavra celebrada. Depois da leitura ritual dos textos sagrados, o homiliasta interpretava e atualizava os acontecimentos salvíficos, levando o povo a responder, para firmar um compromisso que envolvia toda a sua vida na fidelidade à Aliança ${ }^{11}$. Portanto, tanto na linha deuteronomista, como profética, a pregação era sempre feita em assembléias cultuais, onde os chefes, sacerdotes, sábios, escribas ou os próprios fiéis tinham consciência de estarem transmitindo a palavra de Deus, amadurecida pela recordação meditada dos acontecimentos salvíficos e pelo confronto com as novas situações, muitas vezes dolorosas, onde o Senhor continua operando maravilhas e salvando ${ }^{12}$

No Novo Testamento, Lucas mostra Jesus inciando sua atrvidade com uma pregação na Sinagoga de Nazare, nitidamente em contexto cultual (LC $4,15 \mathrm{ss}$ ) e, depois da ressurreição, mostra a comunidade, através do culto, iniciando sua pregação sacramental, quando o Ressuscitado explica as Escrituras aos discípulos de Emaús, texto que nos oferece uma clara intuição de uma celebração eucarística (Lc 24,13ss). Então, em Nazaré, Jesus faz a homilia enquanto Filho de Deus encarnado, e, em Emaús, o Ressuscitado faz sacramentalmente a homilia através dos sinais sensíveis de que dispõe no culto para continuar sua obra sacerdotal até a vinda definitiva do Reino.

${ }^{1 !} \mathrm{Ex}, 24,8$; Js 24; Am 7,12-17; Esd 8, etc.

${ }^{12}$ Cf. DELLLA TORRE, R. Homilia. In: Dicionário de Liturgia, p. 557. 
Portanto, o modelo de homilia se encontra no próprio Jesus, que, em Nazaré, após a leitura do trecho de Isaias, começou dizendo: Hoje se cumpriu a Escritura ${ }^{13}$. Jesus não teceu considerações sobre a vinda do Messias, mas disse: $O$ Messias está aqui e os efeitos da sua presença são visíveis em toda a parte.

Desde então a homilia cono momento liturgico deve fazer o mesmo apresentando Jesus Cristo depois da proclamação ritual da sua Palavra e ao mostrar os sinais da sua presença hoje, convocando a assembléia para uma adesão atual através de posturas adequadas. Feito isto, só resta sentar à mesa do pão e cear como irmãos no mistério onde o próprio Cristo se dá como alimento. Então, os olhos se abrem e todos o reconhecem como Salvador.

Dando seqüência a este processo de interpretação e atualização do mistério da Palavra celebrada, os Atos dos Apóstolos e as cartas paulinas nos apresentam uma série de situações homiléticas que nos servem de exemplo ${ }^{14}$. Estas homilias, de um lado, recordam a promessa profética que evoca a unção do Espírito do Senhor, que escreve suas leis no coração dos homens, fazendo com que cada um compreenda diretamente do Senhor, sem precisar ser ensinado por ninguém ${ }^{15}$. Por outro lado, se processam como um diálogo, segundo o esquema do hagadá pascal ${ }^{16}$. Desta forma, a homilia na liturgia, por causa do seu aspecto sacramental, antecipa a promessa, uma vez que é o próprio Cristo quem ensina através dela.

A igreja continuou a tradição homilética do Novo Testamento, embora tenha modiftcado a palavta grega homilia nara a latina tratus. semo e utilizado muito freqüentenente o verbo predicure? Honilia en grego significa trato, conversação (em primeiro plano); reunião (em segundo); companhia, sociedade, relações familiares, instrução (em terceiro); intimidade (em quarto $)^{18}$. Portanto, muito de acordo com a tradição bíblica.

${ }^{13}$ Lc $4,16-20$

${ }^{14}$ At 13,$15 ; 20,7.11 ; 1$ Cor $11,4 \mathrm{ss} ; 12,8 ; 14,40 ; 1$ Tm $5,19 \mathrm{ss} ; 2$ Tm 4,1-5; Rm 12,6ss; Tt 2,1. ${ }^{15} \mathrm{Jr} 31,33 ; 2$ Cor 3,3 ; 1 Jo 2,20.27; Jo 6,43-47.

${ }^{16} \mathrm{Cf}$. DELLA TORRE, R. Homilia. In: Dicionário de Liturgia, p. 558.

${ }^{17} \mathrm{Cf}$. DELLA TORRE, R. Homilia. In: Dicionário de Liturgia, p. 558.

${ }^{18} \mathrm{Cf}$. PEREIRA, Isidoro. Dicionário Greco-português e Português-greco, p. 404.
Enquanto tal, a homilia mais antiga que chegou até nós foi a Ir carta de Clemente, cujo conteúdo é simples e nitidamente parenético, ou seja, exortativo $^{19}$. O mesmo termo utiliza Justino de Roma, como já vimos acima ${ }^{20}$. Mais tarde, Inácio de Antioquia convida Policarpo a fazer uma homilia contra os ofícios desonestos ${ }^{21}$. Tertuliano alude à escolha de textos bíblicos adequados, "quando os acontecimentos do presente nos obrigam a recordar ou conhecer alguma coisa"22.

Além de sua tradição presidencial, aparece também a partilha da homilia entre vários ministros, como podemos constatar na Didaqué23, no Pastor de Hermas $^{24}$ e no relato de Egéria ${ }^{25}$. Egéria descreve que nas missas dominicais em Jerusalém era costume todos presbíteros concelebrantes que quisessem, pregarem e que, depois deles, pregasse o bispo, para que o povo fosse instruIdo nas Escrituras e no amor de Deus. Isso atrasava bastante o encerramento da Missa.

Gregório Magno concebe o ministério pastoral como uma praedicatio ${ }^{26}$. Temos dele cerca de 600 homilias. Desta forma a homilia vai conquistando um papel muito relevante na celebração dos Mistérios do Senhor. Como as homilias

${ }^{19}$ Parainesis, em grego, significa exortação (primeiro plano); aviso, conselho (segundo); recomendação (terceiro). Cf. PEREIRA, Isidoro. Dicionairio Greco-português e Portiguês-greue. p. 429

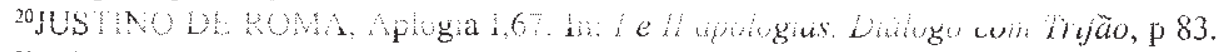

${ }^{21}$ Cf. INACIO DE ANTIOQUIA, Ep. Ad. Pol. 5,1

${ }^{22}$ Aplogeticum 39: conforme citação de DELLA TORRE, R. Homilia. In: Dicionário de Liturgia, p. 558 .

${ }^{23}$ DIDAQUÉ 11,1-2.

${ }^{24}$ PASTOR DE HERMAS, Mand. 11,9.

25 "Sane uia hic onsuetudo sic est, ut de omnibus presbyteris, qui sedent, quanti volunt, predicent, et posit illos omnes episopus predicat, quae predicationes propterea semper dominica diebus fiunt, ut semprer erudiatur populus in Scripturis et in Dei diletione: quae predicaiones dum dicuntur, grandis mora fit, ut fiat missa ecclesia". ITINERARIUM 25,1. In: ÉGERIE, Journal de Voyage (itineraire). Introdution, texte critique, traduction, notes, index et cartes par Pierre MARAVAL. Paris, Les Éditions du Cerf, 1982. p. 246.

${ }^{26} \mathrm{Cf}$. DELLA TORRE, R. Homilia. In: Dicionário de Liturgia, p. 560; 
dos padres doutos tinham sido compiladas em livros, Cesário de Arles, no século VI, pede aos padres e bispos que, se não puderem pregar por si mesmos, leiam as homilias dos antigos padres nas assembléias para a salvação das almas ${ }^{27}$

Assim. as homilias vão tomando forma muito consistente. a partir da patrística. Santo Agostinho intui a perfeita unidade entre os dois testamentos quando diz que "que onde termina a leitura do profeta está a promessa, onde começa a leitura do Apóstolo, está a indicação do que se deve fazer"'28. Insistindo que o ensino não vem do ser humano, mas da unção do Espírito, ele diz: "O que vos transmito não é meu. Eu como o que comeis, vivo do que viveis. Temos uma dispensa comum no céu; com efeito, é de lá que vem a palavra de Deus"29. Para isto, é preciso dar mais atenção à unção do Espírito que aos artificios da oratória: é melhor falar sabiamente que eloqüentemente ${ }^{30}$.

Seguindo esses fundamentos, grandes pregadores que virão mais tarde, como São Francisco de Salles e São Pedro Damião, insistem que o ministério da Palavra exige a coerência e o testemunho. São Francisco Salles diz que o amor é o necessário e suficiente para se fazer uma boa pregação ${ }^{31}$. Também diz Pedro Damião, sobre a idoneidade do pregador: "A integridade da vida vale mais do que a eloqüencia e a elegância refinada das palavras" ${ }^{32}$.

${ }^{27}$ CESÁRIO DE ARLES, Sermo 1,15; apud DELLA TORRE, R. Homilia. In: Dicionário de Liturgia, p. 561.

${ }^{28}$ SANTO AGOSTINHO, sermo 45,1; apud DELLA TORRE, R. Homilia. In: Dicionário de Liturgia, p. 559.

${ }^{29}$ SANTO AGOSTINHO, sermo 95,1; apud DELLA TORRE, R. Homilia. In: Dicionário de Liturgia, p. 560.

${ }^{30}$ SANTO AGOSTINHO, Doct. Chr. 1,4; 5,7; apud DELLA TORRE, R. Homilia. In Dicionário de Liturgia, p. 560.

${ }^{3 !}$ Cf. VIVIES, Martin. Sens et contenu de la prédication. In: Foi e Liturgie: Actes du septième colloque d'études historiqe, theologiqueet canoniques sur le rite romain. Versailles: Centre Internacional d'études litrgiques, a. 2001, p. 273-300.

${ }^{32}$ Epp. Lib. I, Ep. Ad Cinthium Urbis Praef., apud Humani Generis 21

\section{AS HOMOLIAS TEMÁTICAS}

Na escolástica, a pregação assumiu um caráter temático, a partir de uma frase textual da Bíblia ${ }^{33}$. Esta forma complexa de construir temas a partir da Bíblia ajudou a se perder a relação com a vida dos ouvintes. Fazendo frente a isso, nasce a pregação popular, que, preocupada com a vida religioso-moral do povo, utiliza exemplos, narrações e lendas ${ }^{34}$. Desta forma, foi havendo um certo distanciamento entre a pregação oficial e os pregadores populares. A pregação passa a ser um ofício, que não competia mais aos leigos, segundo a determinação de Gregório IX, em $1228^{35}$

Porém, a Igreja enfrentou dificuldades na forma e nos temas da pregação. Leão XIII, em seu motu proprio Sacrorum antistitum, deplora os abusos na escolha dos temas e na forma da abordagem das homilias ${ }^{36}$. Bento XV, em sua encíclica sobre a pregação (15/06/1917), lamenta que muitos pregadores abandonam a Bíblia, os Santos Padres, os doutores da Igreja, os assuntos da sagrada teologia, para ficarem somente em torno da linguagem da razão ${ }^{37}$.

\section{A HOMTLIA A PARTIR DO VATICANO H}

Como diz o Decreto Presbyterorum Ordinis sobre o ministério e a vida dos presbiteros (PO), do Vaticano 11 , "o povo de Deus é reunido antes de tudo

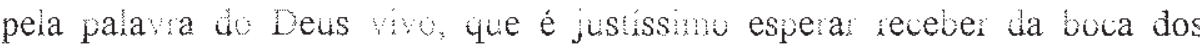
sacerdotes" $^{13}$. Na Constituição Sacrosanctum Concilium sobre a renovação litúrgica (SC), o Concílio, como já dissemos, propõe que a homilia seja parte

${ }^{33} \mathrm{Um}$ tratado do final do século XIII diz: de biblia sumptum habeat sensum perfectum, non nimis longum, non nimis breve, bene quotatum.

${ }^{34}$ DELLA TORRE, R. Homilia. In: Dicionário de Liturgia, p. 561.

${ }^{35} \mathrm{Cf}$. Ibid, p. 561; Cf. CATTANEO, E. La predicazine del laici nel medioevo. In: AA.VV., La predicazione del laici, p. 112-119.

${ }^{36} \mathrm{Cf}$. DELLA TORRE, R. Homilia. In: Dicionário de Liturgia, p. 562 .

${ }^{37} \mathrm{Cf}$. Ibid, p. 567

${ }^{38} \mathrm{PO} 4$ 
integrante da celebração litúrgica, obrigatória nos domingos e nas festividades, que gire em torno dos mistérios do Senhor, segundo o Ano Litúrgico, que tenha como fonte a Sagrada Escritura e a própria Liturgia e que se constitua como um anúncio das admiráveis obras de Deus na história da Salvação, perpetuadas através das ações litúrgicas ${ }^{39}$.

A instrução Inter Oecumenici acrescenta. ainda. que as homilias seiam feitas em algumas férias do Advento e da Quaresma e em outras ocasiões em que os fiéis vão à Igreja com afluência ${ }^{40}$.

Outros documentos conciliares também falam da homilia, salientando que, de forma geral, ela é dever dos ministros ordenados ${ }^{41}$, em continuidade com o mandato de Cristo aos Apóstolos ${ }^{42}$. Por isso, se fala da pregação eclesiástica, que deve ser fundamentalmente alimentada pelas Sagradas Escrituras $^{43}$. O Missal Romano, na sua instrução geral, retoma todas estas afirmações conciliares e insiste no valor e na necessidade da homilia ${ }^{44}$. De forma geral, todos os livros litúrgicos determinam que os Sacramentos sejam celebrados na dinâmica das duas mesas (Palavra e Sacramento) e alguns rituais, como o da Ordem, propõem modelos de homilias escritas no próprio livro litúrgico.

\section{A HOMILIA NO PROJETO LITÚRGICO-PASTORAL}

Podemos então dizer, sem sombra de dúvida, que a homilia brota da mesa da Palayra e deve constituir-se como alimento como diz o Profeta:

${ }^{39} \mathrm{SC} 52 ; 35$.

${ }^{40} \mathrm{Cf} . \mathrm{n}^{\circ} 53$.

${ }^{4 !}$ Dos Bispos (LG 25), dos Presbíteros (PO 4), dos diáconos (LG 29).

${ }^{42} \mathrm{DV} 7$.

${ }^{436 " A}$ Igreja (...) sempre considerou as divinas Escrituras e continua a considerá-las, juntamente com a Sagrada Tradição, como regra suprema da sua fé; elas, com efeito, inspiradas como são por Deus e escrita uma vez para sempre, continuam a dar-nos imutavelmente a palavra do próprio Deus, e fazem ouvir a voz do Espírito Santo através das palavras dos profetas e dos apóstolos. É preciso pois que, do mesmo modo que religião cristã, também a pregação eclesiástica seja alimentada e dirigida pela Sagrada Escritura", DV 21.

${ }^{44}$ IGMR 33.41-42. quando tuas palavras eram apresentadas, eu as devorava; tuas palavras eram para mim contentamento e alegria do meu coração (Jer 15,16). Então o homiliasta sabe que não está tratando de palavras suas, mas da Palavra de Deus. Neste sentido e por respeito à regula fidei, a homilia deve basear-se nas Escrituras e nos textos litúrgicos, entre os quais a oração do dia da Eucaristia é muito elogüente. Tommaso Federici expressa muito hem a organicidade do novo Lecionário em vista de uma homilia bíblica e litúrgica, com as seguintes palavras:

A própria síntese orgânica do novo Lecionário romano exclui os dois tipos mais comuns e deletérios de pregação, a «velha» de tipo moralístico, devocional, individualístico, abstrato da vida e vagamente «espiritual»; e a aparentemente «nova», vagamente psicologista, sociologista, antropologista, politicista. Uma e outra estão fora da verdadeira realidade bíblica e litúrgica. Como o lecionário, a pregação deve ser clara, dar o significado real da Palavra, orientar a solução de cada problema na maturação profunda da consciência cristã operada pela Palavra, e não pretender dar soluções feitas, substituir-se a Palavra com as ideologias burguesas todas desastrosas, opor o homem ao homem e torrar o cristão como aquele que «para alguns» não possa «dar mais o sinal da paz » de Cristo fundado no dom do Espírito Santo enviado pelo Paids.

Então, podemos dizer que a homilia, antes de ser executada, passa por uma mediação hermenêtica a partir de uma exegese bem feita torna-se

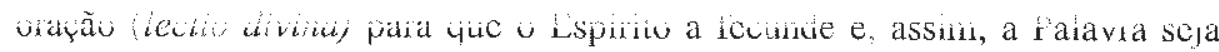
perpetuada e aplicada no hoje da história. A Palavra é única e irrevogável. Por isso, não se pode manipular o texto, para não deteriorar a sua sacramentalidade. Dizia Bento XV, em sua Carta Encíclica sobre a "pregação da Palavra de Deus", que "é uma necessidade absoluta para o pregador ter certo grau de cultura, e quem está privado de sua luz, cai facilmente no erro, como afirmava o Concílio Lateranense: "A ignorância é a mãe de todos os erros"”46. Para

${ }^{45}$ FEDERICI Tommaso, O Lecionário do novo missal romano. Concilium, n, 101, a.1975/2, p. 176 .

${ }^{46}$ HUMANI Generis Redemptionem, p. 17. 
clarear de que ciência se trata, o Papa afirma que se trata do conhecimento de si mesmo, de Deus e da missão recebida ${ }^{47}$. São Pedro Damião diz que "ao pregador duas coisas são sumamente necessárias: profundo e vasto conhecimento dos princípios da doutrina espiritual e o vivo esplendor da vida religiosa"48.

A homilia é exatamente esta apresentação fiel e atual da Palavra com a finalidade de dar graças, lesiemunhar as maravilhas de Deus e realizar o ensino da doutrina cristã pela reflexão entre a Palavra de Deus e cultura, fé e vida ${ }^{49}$. Não tem um tom explicativo, mas entusiasticamente querigmático, pois como diz Della Torre: "Nada é mais nocivo para uma celebração do que um presidente que queira explicar tudo" 50 . Neste sentido, "a tarefa da homilia consiste em ajudar a reconhecer o que era desconhecido, ajudar a dar o nome próprio ao inominado" 51 . É o mesmo que dizer: No meio de vós está alguém que não conheceis; ele vem depois de mim, eu não sou digno de desatar a correia de suas sandálias ${ }^{52}$. Pedagogicamente é bom começar valorizando o positivo do nosso ambiente ${ }^{53}$, para se chegar no núcleo que é o Mistério Pascal, estabelecendo um movimento que vai do Jesus terreno ao Jesus ressuscitado e do Jesus ressuscitado ao Jesus terreno. É o mesmo que dizer que tudo parte de uma assembléia convocada e reunida, que se dirige para a escatologia da glória, mas que reconhece que precisa de indicações éticas claras para poder continuar sua peregrinação na terra. Aqui vale lembrar as sábias palavras de Santo Agostinho sobre a importancia do testemunho que nasce da urąån liturgica

Felizes de nós, se o que ouvimos e cantamos também executamos. A audição é nossa semeadura, e nossos atos, frutos da semente. Disse isto diante

${ }^{47}$ Cf. Ibid, p. 17.

${ }^{48}$ Epp. Lib. I, Ep. Ad Cinthium Urbis Praef., apud Humani Generis, 21.

${ }^{49}$ Cf. DELLA TORRE, R. Homilia. In: Dicionário de Liturgia, p. 567-568.

${ }^{50}$ DELLA TORRE, R. Homilia. In: Dicionário de Liturgia, p. 568.

${ }^{51}$ MALDONADO, Luis. A Homilia, p. 25

52 Jo 1,26-27.

${ }^{53}$ MALDONADO, Luis. A Homilia, p. 27. mão para exortar vossa caridade e não entrardes sem fruto na igreja, ouvindo tantas coisas boas sem realizá-las ${ }^{54}$.

Porém, o pregador deve deixar uma ampla margem de liberdade para a responsabilidade do fiel e não metê-lo numa camisa de força, uma espécie de escravidão.

Segundo o CELAM, a homilia tem três elementos essenciais: elemento exegético, elemento vital, elemento litúrgico ${ }^{55}$. O elemento exegético constitui toda a compreensão correta das Escrituras e dos textos litúrgicos. $\mathrm{O}$ elemento vital seria a interpretação e aplicação corretas das Escrituras em nossa realidade, de tal forma que produza mais vida e combata o pecado e a morte. Já o elemento litúrgico poderia ser a atitude contemplativa de assombrada admiração que a mística desenvolve na liturgia e partir da liturgia, como intui Maldonado ${ }^{56}$

Portanto, a homilia não é nem uma explicação, nem uma exegese e também não uma aula de retórica. Ela não se dirige em primeiro lugar à zona pensante do crente, mas ao núcleo da sua pessoa, ao mais profundo da sua intimidade, ao recôndito do seu ser. Situada no plano existencial, ela deve levar o fiel ao encontro com Jesus de Nazaré, o Cristo da fé

Por isso, a linguagem mais adaptada é a simbólica e emotiva, pois quem prega deve suscitar os sentimentos dos que o escutam. Histórias, parábolas ou nanações vivas puten ajuta nithio a ciarear os significacos e escapar da explicação cansativa. É preciso mergulhar na "arte de narrar"s?.

${ }^{54 \times}$ Felices sumus, si quod audimus et cantamus etiam faciamus. Auditio enim nostra seminatio, operatio autem fructus est seminis. Hoc praelocutus admonuerim caritatem vestram, ne infructuose intretis ecclesiam, audiendo tanta bona et non bene operando", SERMO 23A, 1, CCL 41, 431, apud OFFICIUM Divinum, Liturgia Horarum inxta Ritum Rmanum, IV tempus per annum Habdmadae XVIII-XXXIV, editio typica. Vaticano: 1972. p: 132

${ }^{55}$ CELAM. A Homilia, p. 25ss.

${ }^{56}$ Cf. MALDONADO, Luis. A Homilia, p.121.

${ }^{57}$ Ibid., p. 177 
Para tanto, a preparação para a homilia deve ser geral, remota e próxima. Geral é aquela baseada nos textos da Sagrada Escritura. A preparação remota consiste no primeiro esforço de montagem da homilia, depois de se ter um necessário conhecimento dos textos. Dentro de um plano de fé se vai ruminando também em oração (lectio divina). A preparação próxima é sempre aquela última othada que se dá no esboç da homilia para sc ver se tudo está claro e belo. Com certeza, se terá uma boa homilia.

Sendo parte integrante da celebração, a homilia deve ser feita pelo presidente $^{58}$, que a utiliza como gonzo, dobradiça, entroncamento e elemento conjuntivo a serviço das duas mesas litúrgicas (Palavra e Sacramento) que alimentam o povo de Deus ${ }^{59}$. Se cumprir seu papel, l a homilia será sempre aquela fala esperada, carregada de ensino querigmático, que muito ajudará a assembléia a mergulhar no mistério, a fim de experimentar a presença do Senhor.

\section{Bibliografia}

ADALZABAL, J. Funciona la comunicatión en nuestras celebraciones? Phase, n. 107 a. 1978, p. $459-478$.

ADALZABAL, J. La homilía resituada en la celebración litúrgica. Phıse, n. 91, a. 1976 1. $7-27$

ARMFI INT Femando Celehrndo Prlown Ano A São Mate São Paulo Ave Maria, 2001. 400p.

BAILEY, R.. Del texto ao sermón. Concilium, n. 102, a. 1975 , p. $240-252$

BENTO XV. Carta Enciclica «Humani generis». AAS 9 (1917). pp 305-317; DOCUMENTOS de Pio X a Bento XV (1903-1922). São Paulo: Paulus, 2002. p. 320-335. BULCKENS, J. Como predicar, hoy, la Bíblia? Liturgia, n. 16, a. 1973, p. 91-100. BUYST, Ione. Homilia, partilha da Palavra. São Paulo: Paulinas, 2001. 53p.

\section{${ }^{58}$ IGMR 42.}

${ }^{59}$ CELAM. A Homilia, p. 39
CABALlERO, Basílio. A palavra de cada domingo: Ano C. São Paulo: Paulus, 2000. 334p.

CABALlERO, Basílio, A Palayra de cada dia: comentário e oração. São Paulo: Paulus, 685p.

CAMPRODÓN, J. El sacerdote ministro de la homilía. Phase, n. 18, a. 1963, p. 228-234.

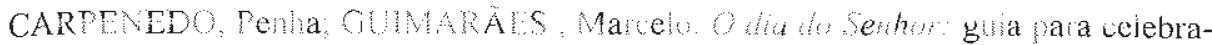
ções para as celebrações nas comunidades. Ciclo do Natal ABC. v. 1. São Paulo: Paulinas - Apostolado Litúrgico, 2002. 223p.

CARVALHO, Dirce de. Homilia: a questão da linguagem na comunicação oral. 2. ed São Paulo: Paulinas, 1993, 432p.

CELAM. A Homilia: o que é? Como se prepara? Como se apresenta?. 5 ed. São Paulo: Paulinas, 1983. 70p.

COMISSÃO EPISCOPAL EUA PARA A FORMAÇÃO SACERDOTAL. Pedagogía actual sobre homilética. Phase, n. 84, a. 1974, p. 494-496.

COOL-VINENT, R. La comunicación en las homilias. Phase, n. 91, a. 1976, p. 55-59.

DELLA TORRE, R. Homilia. In: Dicionário de Liturgia. São Paulo: Lisboa: Paulinas: Paulistas, 1992. p. 555-571.

FEDERICI, Tommaso. O Lecionário do novo missal romano. Concilium, n. 101, a. 1975/ 2, p. $170-180$.

FOURNIER, Elie. La homilia. Barcelona: Estela, 1965. 239p.

GIMBERNAT, A Predicación y critica social phase n 5x a. 1970, p. 385-392

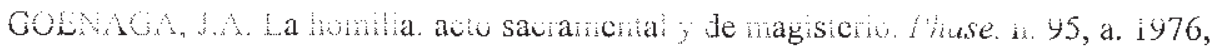
p. 339-358.

GOMIS J. La homilía como problema. Phase, n. 85, a. 1975, p. 55-61.

GOMIS J.. Las homilías vistas por los predicadores. Phase, 61 (1971), 43-50.

GOMIS J. Crisis homiletica, Phase, n. 165-166, a. 1988, p. 256-260.

GOMIS J. Sobre la preparación de la homilia. Phase, n. 56, a. 1970, p. 205-207.

GUIMARÃES, Marcelo; CARPENEDO, Penha. $O$ dia do Senhor: guia para as celebrações das Comunidades. Tempo Comum Ano A. São Paulo: Paulinas - Apostolado Litúrgico, 2001. 408p.

GUTIERREZ, Gustavo. Compartilhar a Palavra no decorrer do ano litúrgico. São Paulo: Paulinas, 1997. 400p. 
MALDONADO, Luis. A Homilia: pregação, liturgia, comunidade. São Paulo: Paulus, 1998. 200p.

NEOTTI, Clarêncio. Ministerio da Palavra: Comentários aos Evangelhos dominicais e festivos Ano A. Petrópolis: Vozes, 2001. 319p.

NEOTTI, Clarêncio. Ministerio da Palavra: Comentários aos Evangelhos dominicais e festivos Ano B. Petrópolis: Vozes, 2002.347p

VITORIO, Jaldemir. O Evangelho de cada dia Ano A: Ano A. São Paulo: Paulinas, $2000.429 \mathrm{p}$.

VIVIES, Martin. Sens et contenu de la prédication. Foi e Liturgie: Actes du septième colloque d'études historiqe, theologiqueet canoniques sur le rite romain. Versailles: Centre Internacional d'études litrgiques, 2001. p. 273-300.

Pe. Valeriano dos Santos Costa é Doutor em Liturgia e professor na Pontificia Faculdade de Teologia Nossa Senhora da Assunção.

\section{VIOLÊNCIA E RELIGIÃO: ALGUMAS AMBIVALÊNCIAS}

\section{Dr. Afonso Maria Ligorio Soares}

Já se passou um ano desde os dramáticos acontecimentos do Onze de Setembro. Muito da poeira já abaixou, mas não é dificil identificar, aqui e ali, sulcos mais ou menos profundos deixados pelo bárbaro espetáculo. Nesse contexto, pode ser proveitoso dedicar algumas linhas ao tema dos vínculos entre religião e violência ${ }^{2}$.

\section{AS RELIGIÕES PREGAM A VIOLÊNCIA? ${ }^{3}$}

Zeferino Rocha entende que a violência atual seja resultado do niilismo ético de nossa cultura contemporânea, que faz com que a barbárie adentre os muros da civilização e se estabeleça entre os próprios responsáveis pelo destino de nossa história ${ }^{4}$. Entretanto, já de início convém admitir que em todos os grandes sistemas religiosos podem ser percebidas relações perigosas entre

${ }^{1}$ Este texio não tem pretensão de originalidade ou de tratamento exaustivo. É um registro de minha conferência no Seminário sobre $A$ Guerra e a Condição Humana, promovido pelo Centro Acadêmico de Relações Internacionais em conjunto com o Centro Acadêmico de Ciências Sociais, a Faculdade de Ciências Sociais e a Coordenação de Relações Internacionais - PUC-SP, no dia 20 de novembro de 2001 O título da conferência - pensada como "palavra provocativa" para um público mais amplo - foi: Violência, guerras e religião.

${ }^{2}$ Aliás, um bom contraponto ao que segue poderia ser o recente artigo de Marcial Maçaneiro, As religiões e a paz, in: TQ - Teologia em Questão, n. 1, a. 2002, p. 7-26. ${ }^{3}$ Para este item e o seguinte, sintetizo o pensamento de HOUTART, François. O culto da violência em nome da religião: um panorama. Concilium, n. 272/4, a. 1997, p. 7-17. ${ }^{4}$ ROCHA, Zeferino. O problema da violência e a crise ética de nossos dias. Sintese, n. 28,92 , a. 2001, p. $301-326$. 